\title{
Wojciech Kaliszewski, Kto królem będzie, czy Polak i który? Wiersze elekcyjne ostatniego bezkrólewia 1763-1764, Warszawa 2003
}

Jerzy Snopek 
Wojciech Kaliszewski, Kto królem będzie, cz)' Polak i który? Wiersze elekcyjne ostatnicgo bezkróleuria 1763-1764, Warszawa 2003, DiG, $290 \mathrm{~s}$.

Okres Oświecenia, a w szczególności czasy stanislawowskie, to epokil obfitująca w burzliwe i dramatyczne wydarzenia polityczne, prowadzące ostatecznie do upadku państwa polskiego. Wydarzeniom tym - zwłaszcza w momentach kulminacyjnych — towarzyszyla bogata ilościowo i zróżnicowana pod względem formy okolicznościowa literatura polityczna. Byla ona w większości wierszowana i przeważnie anonimowa. Krążyła w odpisach rękopiśmiennych, ale niekiedy także w postaci druczków ulotnych.

Literatura ta, pomimo niewielkiej na ogól wartości artystycznej, stanowi cenny dokument historyczny. Jest zarazem świadectwem specyficznej kultury politycznej i literackiej tamtych czasów. Dlatego też od dawna budzi zainteresowanie badaczy naszych dziejów i historyków literatury. Poświęconojej wiele ważnych rozpraw i przyczynków, wydobywając przy tym z rękopisów dość znaczne jej fragmenty.

Wszelako zgłoszony przed kilkudziesięciu juz laty wielki projekt calościowej edycji okolicznościowej poezji politycznej okresu Oświecenia nie zostal dotychczas w pełni zrealizowany. Śmierć najwybitniejszych autorów owego projektu - Romana Kalety i Edmunda Rabowicza - zapewne miała wplyw na opóźnienie prac. Spadkobiercy naukowi (ongiś współpracownicy) i kontynuatorzy wymienionych wyżej uczonych, Zdzisław Maciej Zachmacz i Krystyna Maksimowicz, nie szczędzą trudu, by szczytne dzieło doprowadzić do końca.

Tymczasem kilka cennych edycji ujrzało już światło dzienne. Wymieńmy choćby najdawniejszą z nich Literaturç barską (1976) w opracowaniu Janusza Maciejewskiego, świetne Zagadki Scjmm Czteroletniego, które tuz przed śmiercią zdolal przygotować Ednund Rabowicz (wyd. 1996), czy wreszcie publikacje najnowsze: dwutomową edycję wierszy politycznych Sejmu Czteroletniego, przygotowaną przez Krystynę Maksimowicz z papierów po Rabowiczu (t. 1, 1998; t. 2, 2001) i gruntowne wydanie Wierszy politycznych pieru'szego rozbion i sejum delegacyjnego 1772-1775, przygotowane przez najwybitniejszą znawczynię tych zagadnicú Barbarę Wolską $(2001)$.

W ten szereg prac poświęconych okolicznościowej poezji politycznej polskiego Oświecenia wpisuje się książka Wojciecha Kaliszewskiego, dotycząca „wierszy elekcyjnych ostatniego bezkrólewia”. Przynosi ona zarówno krytyczną ich edycję, jak też obszerną i wszechstronną interpretację. 
Wiersze elekcyjne ostatniego bezkrólewia otwierają niejako dzieje poezji politycznej czasów stanisławowskich. Koncentrują się na wydarzeniu kluczowym dla dalszego biegu spraw polskich, ujawniają gry i intrygi polityczne glównych stronnic tw w walce o wladzę. Głównym bohaterem - pozytywnym i negatywnym - tych utworów jest kontrowersyjny kandydat na króla, Stanisław August Poniatowski. Nie wypadl zresztą z tej roli przez caly okres swego panowania (traktuje o tym niewydana dotychczas rozprawa doktorska Aleksandry Norkowskiej), a oponenci monarchy jeszcze niejednokrotnie wracali do wstydliwych okoliczności elekcji. Wystarczy przypomnieć quasi-zagadkę Sejınu Czteroletniego:

\section{Za swoje piękne powaby Wsadzony na tron od baby. Jeszcze Polacy nie micli Lepszego króla do kądzieli.}

We IVprou'adzenin do książki Wojciech Kaliszewski wytycza precyzyjnie granice chronologiczne swego pola badawczego: 5 X 1763 - sierpień 1764. Interesują go wszystkie utwory wierszowane z tego okresu, odnoszące się do problematyki wyboru króla. Jak pisze (s. 9): „I Iistoryk literatury badający poezję polityczną ma przede wszystkim obowiązek dotrzeć do wszystkich dostępnych i zachowanych tekstów". Jak wolno sądzić, intencja uwzględnienia całości materiału przyświeca Kaliszewskiemu również jako edytorowi „wierszy elekcyjnych”. Tym samym staje obok Rabowicza, wydawcy Zagadek Sejmu Czteroletniego, jako że Maciejewski i Wolska (zob. wyżej) świadomie poprzestali na wyborze, odrzucając znaczną część utworów, które tematycznie kwalifikowały się do edycji.

..Kwerendy w polskich i zagranicznych zasobach bibliotecznych — pisze autor (s. 17) pozwoliły do tej pory odnaleźć ponad trzydzieści, liczących od kilkudziesięciu do kilkuset wersów, w większości nigdy wcześniej niepublikowanych utworów, związanych tematycznie z bezkrólewiem”. Kaliszewski wyraża zarazem - niebezpodstawnie - nadzieję, że ,jest to odpowiadający faktycznemu stanowi ilościowemu korpus tekstów poetyckich, krążących w odpisach w czasie ostatniego bezkrólewia”. Szkoda jednak, że autor nie poszedł tropem wskazań Rabowicza: nie uwzględnil wiersza elekcyjnego Michała Kończy, zamieszczonego w diariuszu sejmowym, nie zweryfikowal sugestii badacza odnośnie autorstwa dalszych wierszy z tego kręgu (Ciapiński, Korycki, Wykowski). Okazja była wyborna i prędko może się, niestety, nie powtórzyć. Na podstawie dawnych swych kwerend mógłbym tu również dorzucić kilka drobiazgów, np. nieznany wydawcy odpis wiersza o incipicie „Chce się Poniatowskiemu, by go królem zwano" (i Respons na to). Kopia ta (rkps Biblioteki PAU-PAN w Krakowie, sygn. 1681) zawiera interesujące odmiany tekstu. W tych samych zbiorach (sygn. 66t) znaleźć też można długi wiersz, który „Imć Pan Rafalski dnia 25 list [opada], to jesı w dzień koronacji napisał i pod nogi J. K. Mci Pana Miłościwego Amno 1764 w Warszawie rzucil". Utwór ten wykracza poza rany czasowe nakreślone przez Kaliszewskiego, ale ewentualnie móglby być uwzględniony jako przypadek graniczny. 
Jak już wspomniałem, zebrane pieczołowicie i wydobyte z wielu źródel teksty stały się — w pierwszej częśsi książki - przedniotem interesıjących rozważań na temat funkcji, jakie pełniły w ówczesnym życiu publicznyın, podloża kulturowego, z którego wyrastały, zaplecza światopoglądowego. Autor jest przy tym w pełni świadomy faktu, że o ksztalcie tego rodzaju utworów w znacznym stopniu decydują także czynniki doraźne, które dziś określilibyśmy mianem socjotechniki. Wszechstromma analiza tych tekstów, poprzedzona bardzo zręcznym zarysowaniem tha historyczno-politycznego, obejmująca zaś również repertuar środków stylistycznych, jakimi autorzy się posługiwali, w istotny sposób dopehnia i wzbogaca cenną edycję (pretendującą do kompletności) wierszy politycznych ostatniego bezkrólewia.

$$
\text { Jerzy Snopek }
$$

\section{Agnieszka Bąbel, Muza z warzachu'iq. Un'agi o literaturze i kulinariad, War- szawa 2004 , IBL}

Wśród „złotych myśli” Karela Čapka znajdziemny taką konstatację:

Dobry przepis kucharski jest jak dobry dramat: im mniej stów, tym lepsza treśćl.

Autorka $M u z y^{\prime} z$ u'arzq̨ihu'ią, dostosowując miejscami poetykę swej książki do opisywanego przez siebie zjawiska wzajemnego przenikania się gastronomii i literatury (patrz tytuły rozdziałów: Nieco o sktadnikach; Szczypta historii; Naczynie i jego zan'artośc; Rzeczo omieszaniu; Przepis na bohatera; Ménu przyszłości), „sporządzila” dziclko niewielkie, ale o interesującej i wyczerpującej treści. Rozdział wstępny (Nieco o skłładnikach) koníczy się obserwacją, że „chociaż wszyscy jedzą, niezbyt wielu potrafí o jedzeniu pięknie pisać" (s. 12). Agnieszce Bąbel udała się ta sztuka - niewątpliwą zaletą książki jest to, że przy ogromie wykorzystanego materiału i dużej wartości informacyjnej napisana jest gładkim, potoczystym językien.

Najogólniejszą intencją pracy jest „naszkicowanic rozmaitych rodzajów wzajemmych powiązań między tekstem kulinarnym a tekstem literackim”. Autorka dąży do „ukazania «literackości» przepisu kulinarnego zarówno w perspektywie jego historycznego rozwoju oraz swoistej poetyki, jak i - obszerniej - w pewnej konkretnej epoce", ale śledzi też motywy kulinarne w literaturze pięknej różnych epok (od czasów antycznych po wick XX). Zauważa przy tym, że owe wzajemne powiązania zachodzą zarówno na planie formy, jak i treści, co obrazuje interesującymi przykładami.

Zajmując się tym szczególnym gatunkiem literatury uzytkowej $j^{2}$, jakim jest przepis kuchenny wzbogacony o komentarz historyczny, kulturowy czy obyczajowy, autorka formulu-

'K. Capck, Affor zm)', wyb. i wst. II. Janaszck-lvaničková, Warszawa 1984, s. 105.

`Synonimani są tu terminy: literatura brukowa, rynkowa, popularna. Nic pada natomiast określenie .paraliteratura". powszechnic stosowane przez badaczy anglosaskich, francuskich ezy hiszpańskich, także w odnicsicniu do tckstów kulinarnych. 